\title{
The Activities of the Eastern Province Section of the South African Chemical Institute 1935-1965
}

\author{
Peter Loyson iD $\$$ \\ Chemistry Department, Nelson Mandela University, Port Elizabeth, South Africa.
}

Received 14 April 2019, revised 17 December 2019, accepted 18 December 2019.

\begin{abstract}
This article traces the activities of the Eastern Province (EP) Section of the South African Chemical Institute (SACI) from its founding in 1935 to the formation of the University of Port Elizabeth in 1965. The EP Section was only the third Section of the Institute to be formed in South Africa and was very active with regular meetings being scheduled. These meetings dealt predominantly with industrial and applied chemistry topics, indicating very strong interaction between industry and the Chemical Institute. Pure academic topics were presented under the auspices of the Chemistry Department of Rhodes University in Grahamstown (Makhanda). During this period, the EP Section hosted three National Conventions and produced two Presidents of SACI.
\end{abstract}

KEYWORDS

SACI, EP Section, history, first 30 years.

\section{The Years $1935-1945$}

According to the minutes of the 23rd Annual General Meeting of the South African Chemical Institute (SACI) held on 19th June 1935, an application for the formation of a Local Section was received from members resident in the Eastern Districts of the Cape Province. Until then Pretoria and Natal were the only Sections of the Institute which existed. The application was approved, ${ }^{1}$ making the Eastern Cape the third Section of SACI. Only in March 1942 was the Western Cape recognised as a new Section. ${ }^{2}$

The driving force behind the creation of the Eastern Province Section of SACI was Prof. William Frances Barker, Head of the Chemistry Department at Rhodes University College (later University). He was to be chairman of the Section for a period of 12 years (1935-1947). ${ }^{3}$ Other members of the founding committee were: vice-chairman A. Gardner, and honorary secretary L.-F. Addis-Smith; additional members of the committee were A. Louden, S.A. Spencer, T. James and T. Zadkin. ${ }^{4}$

Meetings were held at the Technical College in Port Elizabeth, PE, (Fig. 1) four times per year. Prof. Barker had to make the trip from Rhodes University (Fig. 2) in Grahamstown to Port Elizabeth in order to attend these meetings, in some cases under difficult conditions. ${ }^{3}$ The Section was small, starting with 10 members in $1935,{ }^{7}$ which grew to 16 members in $1941 .{ }^{8}$

An interesting event took place during 1935 at the Rhodes University College when Mr S.G. Shuttleworth received the James Moir Medal in recognition of his M.Sc. thesis and a prize of 10 pounds. The title of his thesis was 'The Determination of $\mathrm{N}_{2}$ in leather'. ${ }^{9}$ Stanley Shuttleworth would later make a significant impact on the leather industry in South Africa and particularly in the Eastern Province. ${ }^{10,11}$

Consulting the archives of SACI provides information about the types of lectures presented during this early period. They were generally of an industrial nature with an emphasis on the chemistry of leather, the manufacture of cement and aspects of the chocolate and food industry. Some of the lectures presented

\footnotetext{
* To whom correspondence should be addressed. E-mail: ployson@nmmu.ac.za
}

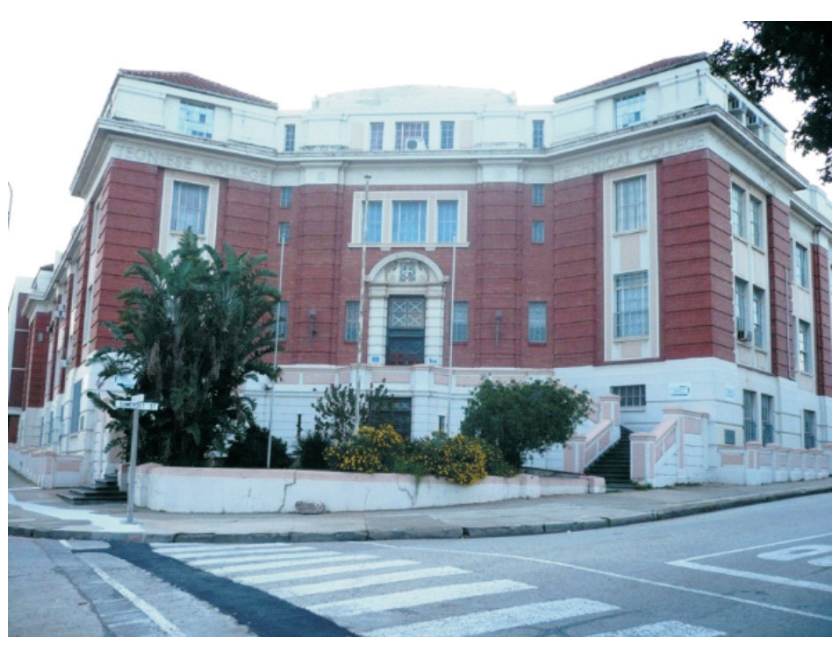

Figure 1 The PE Technical College in Russell.

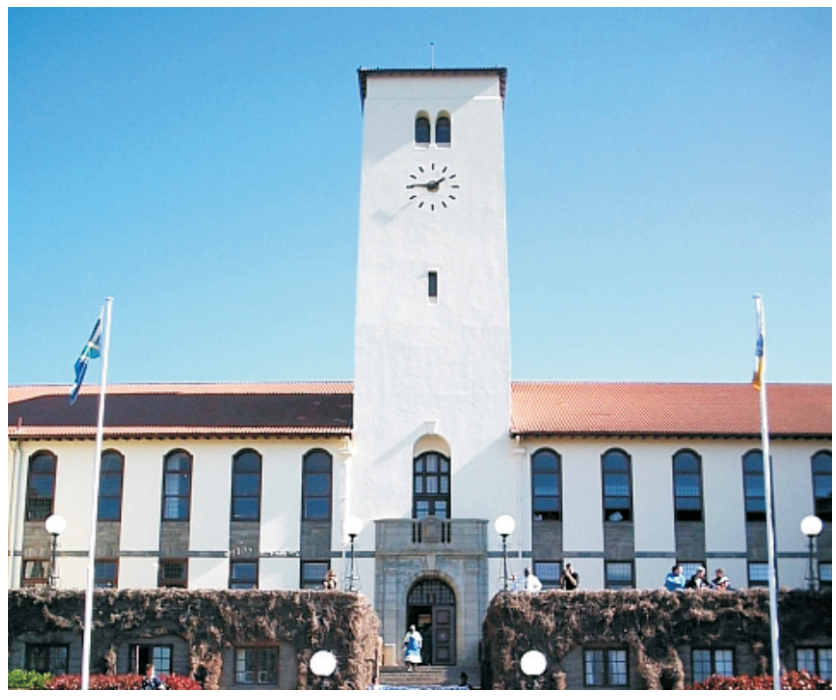

Figure 2 The iconic tower of Rhodes. 
were also of an academic nature. The titles of these presentations are given below with the years mentioned running from June to June:

1935-1936: Chemical changes (Barker), The quest for purity of products (Addis-Smith), Manufacture of cement (Spencer), The science of leather manufacture (Gardner). ${ }^{12}$

1936-1937: Modern methods of chemical analysis (W.F. Barker), Free radicals (T. James), Manufacture of leather (S.G. Shuttleworth), Some chemical aspects of rubber (P. Mitchell). ${ }^{13}$

1937-1938: Anaesthetics (Dr Moore Dyke), Some aspects of forensic chemistry (R. Coppin), The chemistry of canning (Dr B. Gershill), Floods, droughts and the future (Barker). ${ }^{14}$

1938-1939: Use of UV light in analytical chemistry (AddisSmith), Development of a scientific outlook (R. Schauder), Poisons (R. Coppin), The mineral resources of South Africa (Prof. E.D. Mountain). ${ }^{15}$

1939-1940: 100 years of photography (J. Sebba), Plastics (V. Morris), Cocoa and chocolate manufacture (J. Hunter) ${ }^{16}$

1940-1941: Analytical chemistry of Se and Te (D.J. Gray), Chemistry of tanning materials (Dr L. Jablonski), Drug analysis (Addis-Smith), Soap manufacture (D.E. Wigzell). ${ }^{17}$

There is very little information available from the archives regarding the war years 1942-1945, but in 1941 the committee still consisted of Prof. Barker (Chairman), Gardner, James, Spencer and Addis-Smith as Secretary. ${ }^{17}$

At this point it is worth taking a closer look at three important men who founded the EP Section of SACI.

\section{a) Prof. William Frances Barker (1901-1974): Founding Chairman (1935-1947)}

Born in Ilkley, Yorkshire, Barker, shown in Fig. 3, was educated at the Grammar School in Ilkley and the University of Liverpool, where he obtained a First Class Honours in Chemistry in 1920 and his Ph.D. in 1922. ${ }^{3}$ He carried out further research in photochemical reactions and became a chemistry lecturer at the University of Cape Town in 1925. Later that year he was appointed Professor of Chemistry at Rhodes University College, succeeding the late Prof. George Cory. ${ }^{3}$ He held this position with distinction for 36 years. In addition, he served six years as Dean of the Faculty of Science and was for 30 years on the Senate of the University of South Africa. ${ }^{19}$ In 1938 Prof. Barker initiated

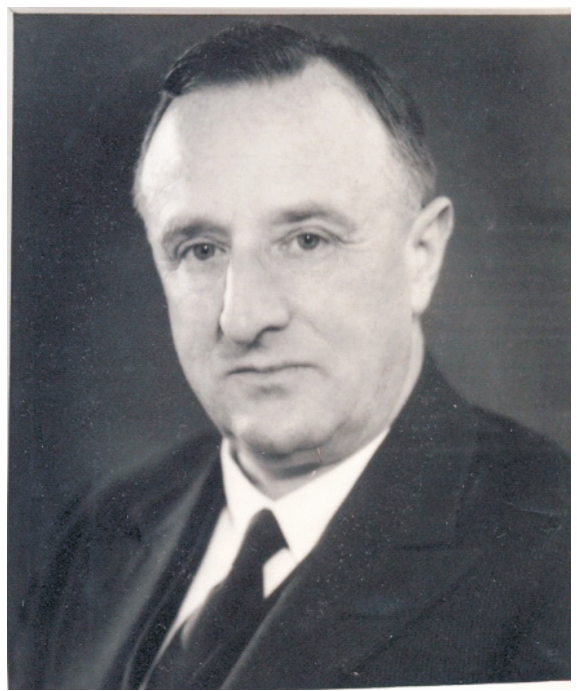

Figure 3 Prof. W.F. Barker. ${ }^{18}$ the founding of a Department of Tanning, Hides and Skins Research. This later became the Leather Industries Research Institute (LIRI) of which he was a Director until 1941. ${ }^{3,19} \mathrm{He}$ became President of SACI for the year 1942-1943.18

His research interests covered a very wide field including spectroscopy, photochemical reactions, carotenes and their behaviour on oxidation and the isolation of hexoses from irradiated solutions of formaldehyde. He also worked on vapour pressure measurements of sulphuric acid / water mixtures, the antimonyl electrode, and the analysis and testing of leather and tanning extracts. In addition, he researched conductometric titrations and determined traces of Se and Te in blister copper and copper concentrates. He studied soil erosion problems, carried out statistics of soil sampling, and other activities. ${ }^{3}$

After his retirement from Rhodes University in 1961 Prof. Barker taught chemistry at several universities in the USA, his last post being visiting professor at Kent State University. ${ }^{19}$

A tribute to the teaching ability of Prof. Barker is the fact that in 1974 at least seven South African Universities had professors of chemistry, who were former students of Prof. Barker. In addition, two Directors of Research Institutes were also his past students. ${ }^{19}$

An article from 2004 entitled '100 Years of Chemistry at Rhodes University' provides some additional information about the enduring legacy of Prof. Barker. ${ }^{20}$ E.F.C.H. Röhwer was one of the first students to do an M.Sc. under Barker in 1935 on the topic of 'Conductometric analysis of leather extracts and tanning liquors'. He would later become professor of inorganic chemistry at the University of Stellenbosch. ${ }^{20} \mathrm{~S}$. Shuttleworth, who received the James Moir medal in 1935, was the first Rhodes student to be awarded a Ph.D. degree and later became the first director of LIRI. ${ }^{20}$ Another student, D. Roux, became professor of organic chemistry at the University of the Orange Free State in Bloemfontein and became a world authority on the chemistry of flavonoids. ${ }^{20}$ E. Verdier completed his M.Sc. in 1935 in electrochemical analysis of soils and studied polarographic analysis under its inventor Heyrovsky in Prague. Later he completed a doctorate at the Sorbonne in Paris and went on to become professor of electrochemistry at the University of Montpellier in France. ${ }^{20} \mathrm{~W}$. Steyn obtained his Ph.D dealing with trace metals in citrus and pineapple production; in 1962 he became professor of inorganic chemistry at UNISA. ${ }^{20}$ The field of electrochemical conductance had an active group guided by J. Gledhill, later professor of physics and electronics at Rhodes, and P.K. Faure, future professor of inorganic chemistry at the Rand Afrikaans University. ${ }^{20}$ Another scholar was H. Govinden, who was involved in electrochemical research, and would become professor of physical chemistry at the University of Durban-Westville. $^{20}$

Amongst the excellent organic chemists from Barker's Department were B. Campbell and G. Cragg (later at UCT), G. McGillivray (UNISA) and A. Howard and G. Gerrans (University of the Witwatersrand), amongst others. ${ }^{20}$ Dr E.G. Prout joined the department in 1956 and developed a strong research group in solid-state chemistry with P. Herley who was one of his Ph.D. students. Herley later moved to the United States and in 1971 he became professor of chemistry and of material science and engineering at the State University of New York. ${ }^{20}$

\section{b) Alexander Gardner (1901-1965): Vice-chairman}

Gardner, shown in Fig. 4, was born in Glasgow and matriculated at Durban High School at the age of sixteen, being the top student in Natal. He then attended Natal University College in Pietermaritzburg and obtained a B.Sc. degree, being the first 


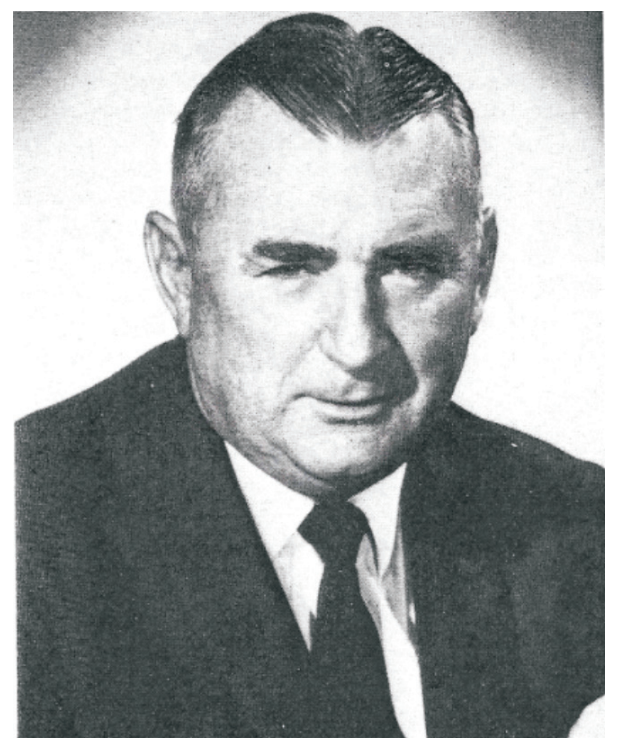

Figure 4 A. Gardner. ${ }^{18}$

man in South Africa to become a leather chemist. He continued his studies at Leeds University, England, where he obtained his M.Sc. degree in the Leather Department at the age of 21 . He worked as a chemist in a tannery in Glasgow for a few years before returning to South Africa in May 1927 to take up the post of Head of the Leather Trades Department at the PE Technical College. This Department specialized in boot and shoe manufacture. ${ }^{21}$

In 1929 he started a Chemistry Department at the PE Technical College, mainly to provide classes for Pharmacy students, but also to give courses in industrial and analytical Chemistry. He became the first Head of Chemistry at this institution. At this time the Pharmacy Board of South Africa had agreed that the Port Elizabeth Technical College, along with the Natal Technical College, the Witwatersrand Technical Institute and the Cape Technical College, would be recognized as institutions at which courses for both the Preliminary Scientific and Qualifying Examinations for Druggists and Chemists (pharmacists) could be taken. $^{22}$

During 1930 Alexander Gardner left the PE Technical College to act as a consultant for the tannery of Bagshaw Gibaud, a large leather company in Port Elizabeth. His practical work in the tannery was so impressive that he was offered a permanent appointment with the firm the following year. ${ }^{21}$ For the next 33 years he devoted his services to the welfare of the tannery and eventually rose to become Managing Director. In conjunction with Professor Barker of Rhodes University, he laid the foundations of the Leather Research Institute, later to become the Leather Industries Research Institute. ${ }^{21} \mathrm{He}$ was very active in SACI matters often taking over as Chairman when Prof. Barker was absent.

\section{c) Laurence-Frederick Addis-Smith (1904-1965): Honorary Secretary}

Addis-Smith, shown in Fig. 5, was born in London, obtained an M.Sc. in pharmacology and joined the PE Technical College to teach Pharmacy and Chemistry from 1933 to 1944, after which he joined the Adhesive Company, A.M. Bach, in PE. ${ }^{23}$ He was very active in chemistry circles, being Chairman of the National Convention in 1951 (to be discussed later). He became the 40th President of the SA Chemical Institute for the year 1951-1952.18 He emigrated to New Zealand in 1954, joining the Chemical Services Laboratories in Johnsonville, Wellington. ${ }^{24}$

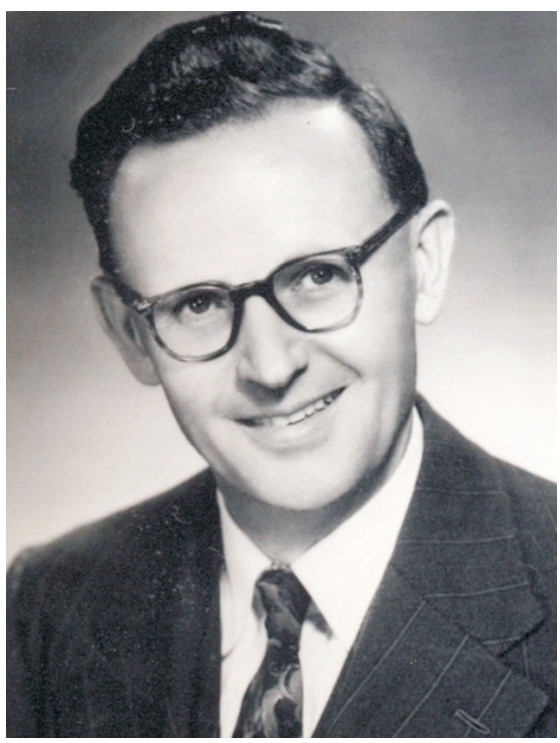

Figure 5 L.-F. Addis-Smith. ${ }^{18}$

\section{The Years 1946-1955}

According to the Annual Report for the Eastern Province Section for the period June 1946-June 1947, Prof. Barker was still the Chairman whilst Raphael Schauder was the Honorary Secretary and Treasurer. ${ }^{25}$ Other new members on the committee were Dr O.G. Backeberg and Mr K.A. Murray. In June 1946 the membership of the local Section stood at 47 , a significant increase from 16 in June 1941, indicating strong growth during the war years. In June 1947 membership stood at $51 .^{25}$ The Section had expanded its activities to include Chemical Engineering, as can be seen from the lectures presented.

The following Engineering lectures took place during the period June 1946-June 1947: 'Aptitude testing in industry', 'Boiler feed water treatment', 'Chemical engineering problems in the tanning industry' by Hyman Schauder and 'The advent of the alkali industry in Great Britain' by C. Price. ${ }^{25}$

Other lectures were: 'Chemistry: random thoughts on yesterday and today' (Prof. Barker), 'Sampling errors in analysis with special reference to soils' (W. Steyn), 'Atmospheric corrosion in Port Elizabeth: a policy for the future' (R. Schauder), and 'Analytical aspects of soaps and allied products' (K.R.C. Keays). ${ }^{25}$

In June 1947 Prof. Barker handed over the chairmanship of the EP Section to L.-F. Addis-Smith. The committee was as follows: vice-chairman A. Gardner, honorary secretary and treasurer R. Schauder, and additional members T. James, C.H. Price, N. Emmerson and Dr E.P. Stevens. ${ }^{26}$

During that year R. Schauder presented a talk on his recent tour of the Union, covering visits to the Umtata hydroelectric plant, the Wattle industry in Natal, the gold and chromium mines in Rhodesia (now Zimbabwe), and alluvial diamond diggings. He placed special emphasis on possible raw materials for the chemical industry. ${ }^{27}$

Later in 1948 a talk was given by M.M. Renfrew, Director of ICI Plastics Division, entitled 'Modern developments in plastics'. Another activity was a visit to the Uitenhage Goodyear Tyre Company, where 30 people were informed about the various processes to make rubber tyres and tubes. Further activities for the year were lectures covering Wattle research: 'Prevention of colour in Wattle bark', 'Wattle extract' and 'Wattle tanned leather' by D.G. Roux of the Leather Industries Research Institute. ${ }^{27}$

Members and their wives had the privilege of attending a function on the 1st of June 1948 in honour of Professor and Mrs 
Alexander Findlay, Past President of the Royal Institute of Great Britain and Ireland. ${ }^{27}$

For the period 1949-1950 a new Chairman was elected. Dr E.P. Stevens, shown in Fig. 6, had a Ph.D. from London, specializing in pharmaceutical chemistry. He lectured in pharmacy at the PE Technical College. The Honorary Secretary and Treasurer was R. Schauder with committee members A. Gardner, Dr C. Maunder-Foster, L.F. Addis Smith, C.R Price, N. Emmerson and T. James. The membership stood at $50 .^{28}$

The following presentations were offered during the year: 'Raw materials of tomorrow' by L.-F. Addis-Smith, 'Geology and mineral resources of Port Elizabeth and District' by R. Schauder, 'Corrosion problems in industry' by the CSIR, 'Dyestuff manufacture' by P. Cooke, 'Synthetic detergents in the textile Industry' by C.A. Norris and 'Industrial applications of surface wetting agents' by A. MacArthur. In addition, various plant visits were organized such as the Carburetted Water Gas Plant of the Municipality and Aberdare Cables. ${ }^{28}$ It can be observed that the presentations offered were generally of an industrial chemistry nature.

For 1950-1951, Dr Stevens was still the Chairman with a new person V. Morris sharing secretarial duties with R. Schauder. Two additional new members of the committee were H. Fry and F.G. Thompson; the membership had grown to $58 .{ }^{30}$

The following lectures were presented: 'Research' (Dr Stevens), 'The research chemist and scientific instruments' (H. Fry), 'The utilisation of South African raw materials and the work of the National Chemical Laboratory' (Dr Rapson from the Council of Scientific and Industrial Research, CSIR), 'Gas production' (C. Fuller-Petersen), 'The training of chemists' (Prof. Barker), 'Adhesives in industry' (L.-F. Addis-Smith) and 'The facilities and services of the National Physical Laboratories' (Dr S.M. Naude, CSIR). ${ }^{30}$

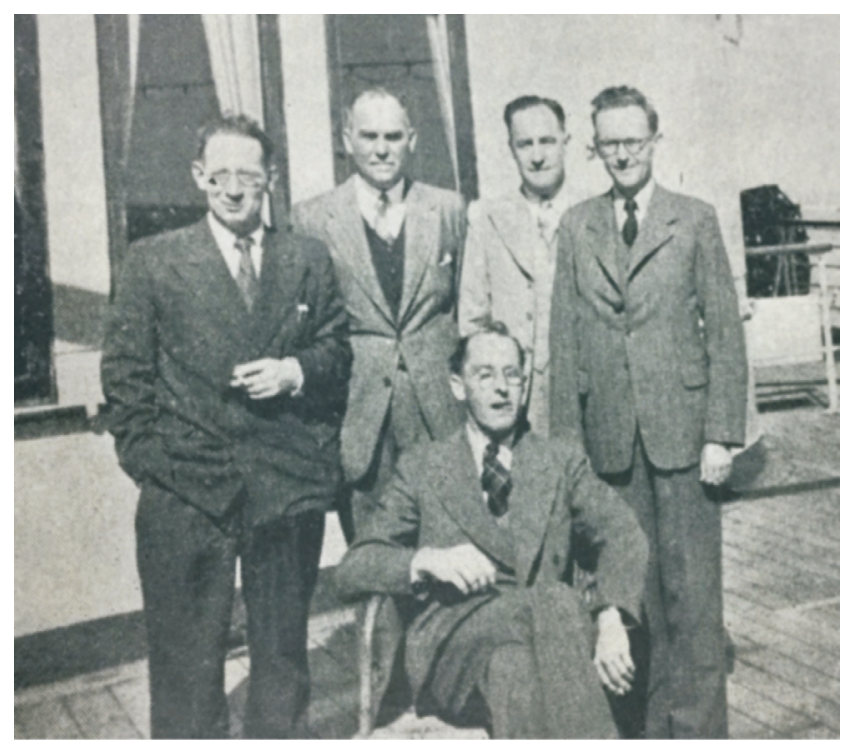

Figure 6 Members of the EP Section Committee in 1949 during a visit of C. Lindeman to the region: Chris Price, Lindeman, Raphael Schauder and Laurence-Frederick Addis-Smith. Seated: Dr E.P. Stevens, Chairman. $^{29}$

\section{5th National Convention of SACI in Port Elizabeth}

From 1-6 October 1951 the EP Section of SACI hosted the 5th National Convention at the PE Technical College under the chairmanship of L.F. Addis-Smith. The multi-disciplinary nature of this Convention is illustrated by the participating Societies namely the South African Chemical Institute, the Society of Leather Trades Chemists, The Institute of Sewage Purification and the SA Institute of the Boot and Shoe Industry. ${ }^{31}$
Rhodes University 's Chemistry Department was the venue for the 2nd day of the Convention where the following lectures took place: 'Measurement of electrical conductivity' (Dr J.A. Gledhill), 'Pure water' (P.K. Faure), 'Solubility by electrical measurement' (G. Malan) 'Differential polarography' (Dr E. Verdier) and 'The determination of some plant nutrients in soil' (W. Steyn). Later that day there was a visit to the Leather Research Institute and a lecture by Dr S, Shuttleworth on 'Chemistry of chrome tanning ${ }^{\prime}{ }^{31}$

The remainder of the Convention took place at the PE Technical College. The sessions on the chemistry of rubber covered processing of compounded rubber for tyres, the curing of rubber and practical rubber compounding. The wool and textile technology sessions covered such lectures as synthetic fibres and wool, wool scouring and wash effluent treatment. A symposium on the characteristics of heavy leather and certain synthetic materials in relation to footwear manufacture was also included as part of the programme. In the field of chemical engineering there was a lecture by Dr C.A. Maunder-Foster from General Motors SA entitled 'The costing of a chemical process'. There was also a symposium on composting covering such lectures as municipal composting and its economics and refuse disposal, amongst others. In addition, visits were organized to the new sewage works at Uitenhage. ${ }^{31}$

For the year 1952-1953 there were two Chairmen of the EP Section: Dr C.A. Maunder-Foster and Mr R. Schauder. The Secretary was V. Morris and committee members were: L.-F. Addis-Smith, W.Z. Poklewski, F.G. Thompson and B.H. Dorfling. The following lectures were presented: 'Resorcinol - a plastic Intermediate' (Dr G.E. Little), 'Rubber grows up' (at Rhodes University, V. Morris), 'Demonstration of glass blowing' (F. van der Water), 'Chemicals from petroleum' (R. Paget) and The Presidential Address by L.-F. Addis-Smith, who was President of the SA Chemical Institute for 1952-1953. During this year the committee lost two important members, both having served as Chairmen. Dr Maunder-Foster returned to England, whilst Dr Stevens went to the U.S.A. Mr R. Schauder took over as chairman when Dr Maunder-Foster left. ${ }^{32}$

The year 1953-1954 saw R. Schauder as Chairman and V. Morris as Honorary Secretary and Treasurer; other members of the committee were: Thompson, Addis-Smith, Poklewski, J.R. Perrott and R. Paget. The following meetings were presented: 'The chemist in the sugar confectionary industry' (J.M. Tucker), 'Heat utilisation and economy in industry' (Dr A. Petrick and Dr O. Volckman, from CSIR). There was a farewell function for Mr L.-F. Addis Smith who was leaving for New Zealand. ${ }^{33}$

For the year 1954-1955 the E.P. Section had the same committee with M.S. Chazan replacing L.-F. Addis-Smith. The following activities took place during the year: 'Impressions of scientific interest from abroad' (R. Schauder), 'Corrosion' (W.J. Copenhagen), 'Safety in the chemical industry' (S. Sinoff), 'Soil fertility in tropical Africa' (Dr H. Vine), 'South African clay problems and research' (H. Heystek) and 'Physics in relation to industry' (Symposium). There was also a visit to the new salt works, SALNOVA, at Coega. ${ }^{34}$

\section{The Years 1956-1965}

An interesting article entitled 'Waste - South Africa's challenge and opportunity' appeared in The South African Industrial Chemist journal of June 1956. It was written by Mr Hyman Schauder, shown in Fig. 7. He was Chairman of the Midland Regional Research Committee of the CSIR and Director of A. Schauder 


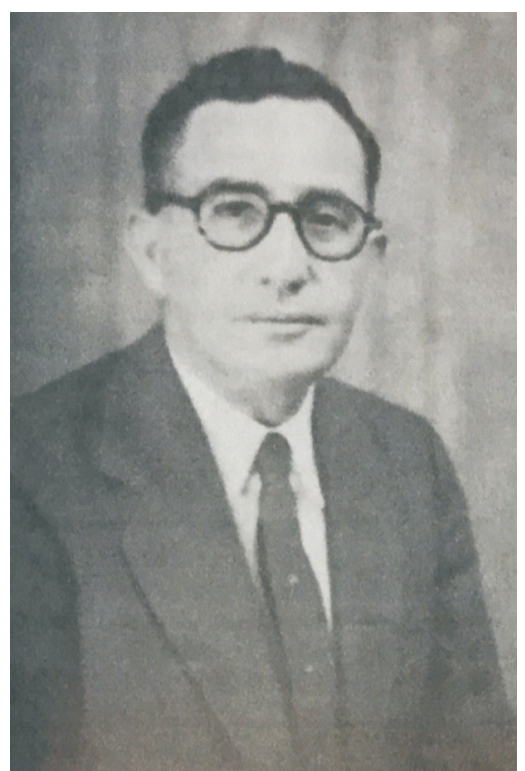

Figure $7 \mathrm{Mr} \mathrm{H}$. Schauder. ${ }^{35}$

and Sons (Pty) Ltd. ${ }^{35}$ Hyman (Hymie) Schauder, Raphael Schauder's brother, was a chemical engineer and economist, whilst his wife Effie was an industrial chemist. ${ }^{36}$ In the article he advocated better utilisation of cellulose resources by collaboration between the Chemical and Agricultural Industries. He discusses in detail the various wastes streams generated and suggests ways of utilising this waste by conversion into more useful products. ${ }^{35}$

The committee for 1957-1958 had Dr P.K.F.J. van Gent as Chairman. He had a Doctorate in engineering, an M.Sc. degree in Science and a Higher Education Diploma. ${ }^{37}$ The Honorary Secretary and Treasurer was Mr J.R. Perrott. Committee members were: R. Schauder, V. Morris, R. Paget, M.S. Chazen and N. Cudmore. The Section, which totalled 52 members, had a very active year, with two work visits and nine meetings. ${ }^{38}$

\section{2th National Convention at the PE Technical College}

The year 1958 saw the hosting of the 12th Annual Convention of SACI in Port Elizabeth from 14-18 July. The Convention took place at the PE Technical College and V. Morris, shown in Fig. 8,

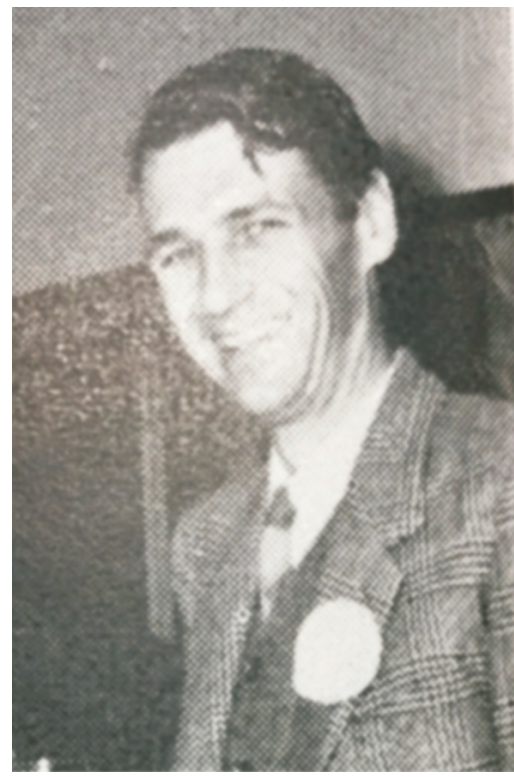

Figure 8 V. Morris. ${ }^{41}$

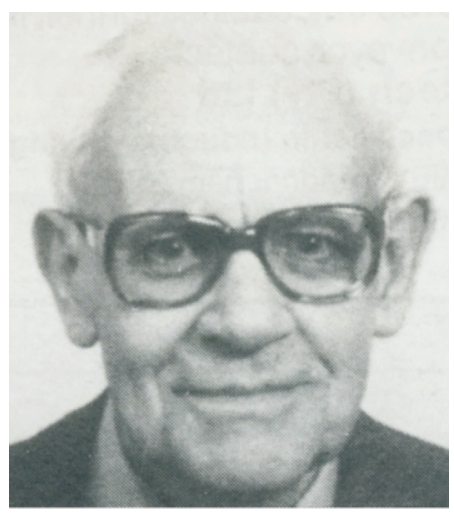

Figure 9 Dr P.K. van Gent. ${ }^{37}$

was the organizing chairman. He was born in Queenstown in 1918, educated at Queens College and graduated with a B.Sc. degree at the University of Stellenbosch. He joined Firestone as an industrial chemist in 1938 and after several training visits to the United States was appointed Chief Chemist at the local plant. He was appointed Production Manager of Firestone SA in 1957.39

The first day of the Convention was devoted to salt technology, food chemistry and construction materials. Dr A.J. Rossi presented a lecture on 'Modern technology of salt' with a subsequent visit to the SALNOVA plant in Coega. This was followed by a lecture entitled 'The work of the state food chemist' by Dr P.K. van Gent, shown in Fig. 9. The third lecture of the day dealt with chemically resistant new materials for construction in the chemical industry, presented by D.J.S. Gray. ${ }^{40}$

The next day saw presentations on the chemistry and engineering of timber preservation (J.E. Furze) and aspects of dust and mist control (Prof. F.H.H. Valentin of the University of Natal). In the evening there was a very well attended lecture in the City Hall by Dr Arthur Bleksley, the well-known astronomer, on future space travel. ${ }^{40,41}$

The third day of the Convention took place in Grahamstown and was dedicated to Wool Research: a lecture by Dr D.P. Veldsman on the scouring of South African wool, followed by weathering in wool by Dr C.C. Kritzinger. There were also visits to the Wool Research Institute. ${ }^{40,41}$ Two lectures were presented on the final day: 'The chemical effects of radiation' by Dr M. Peisach, and 'Treatment of salt water by electrodialysis' by J.R. Wilson. ${ }^{40,41}$

For the year 1958-1959 the committee was essentially the same as the previous year except that P. Bloom replaced R. Paget. The following lectures were offered: 'River pollution and assessment of standards' (H. Bruggeman); 'An overseas interlude' (Prof. Barker); 'Some aspects of cereal chemistry' (N. Cudmore); 'Thin films on glass' (H. Fry); 'Chemicals and the timber industry' (Dr Baskind); 'Atmospheric pollution' presented by the SA Medical Association and the EP Society of Engineers. ${ }^{42}$

The most popular presentation was the one dealing with river pollution by Bruggeman, which led to animated discussions. Hyman Schauder outlined proposed investigations of the pollution of the Zwartkops River by a team from the CSIR and the Department of Water Affairs in cooperation with the Port Elizabeth Municipality. ${ }^{43}$

The year 1959-1960 saw a committee chaired again by Dr P.K. van Gent. The secretary was J.R. Perrott and members were R. Schauder, P. Bloom, M. Chazen, J. Tucker and N. Cudmore. During this year the following presentations were offered:44 Prof. Erdtman and his wife Dr Aulin gave a talk on Swedish 
forests and Miss E. Lumsden lectured on the narcotic drug laboratories of the United Nations. Further, R. Coppin gave a talk on Chemistry and Crime; B.M. Midwidsky presented 'The Technology of Oils, Fats and Waxes'; R. Teichmann talked on 'The SABS (South African Bureau of Standards) in relation to the timber industry'; Dr H. Irving lectured on chelatometric titrations; R.V. Curten discussed acrylic resins, their chemistry and applications. A function was organised to bid farewell to V.A. Morris, who had played an important role in the Section over the past few years.

For the year 1960-1961 Dr P.K. van Gent was again Chairman with Mr J. Tucker, shown in Fig. 10, acting as vice-chairman and Mr J.R. Perrott as secretary. ${ }^{45}$ In May 1961 the committee bade farewell to the Chairman Dr P. K. van Gent who was transferred to Johannesburg. He had been the Senior Government Analyst in Port Elizabeth for the past 11 years and the Chairman of the Eastern Province Section of SACI for 4 years. ${ }^{37,46}$ During his chairmanship he fostered interest in chemistry amongst the community in general. He wrote an important paper, published in The South African Industrial Chemist in 1959, covering the work of the Government Food Chemist. ${ }^{47}$ In this article he argued that food chemists had only recently been accepted and appreciated. He provided the historical background for the acceptance and necessity for the control of quality and safety in foodstuffs, reviewing several of the common aspects of control. He would later be well-known for his important work dealing with blood-alcohol analysis. ${ }^{48}$

Mr J.M. Tucker (1898-1966) took over as Chairman. He came from Cornwall in England and obtained his B.Sc. Degree from London University. He qualified as a Food Chemist by successfully passing the Fellowship Examinations in food chemistry from the Royal Institute of Chemistry. He worked for various food industries and in Port Elizabeth for Algoa Sweets and Glenton/Mitchell until the time of his death. He was to be Chairman from 1962 to 1965, an active member of the Institute and highly regarded by everyone. ${ }^{49}$

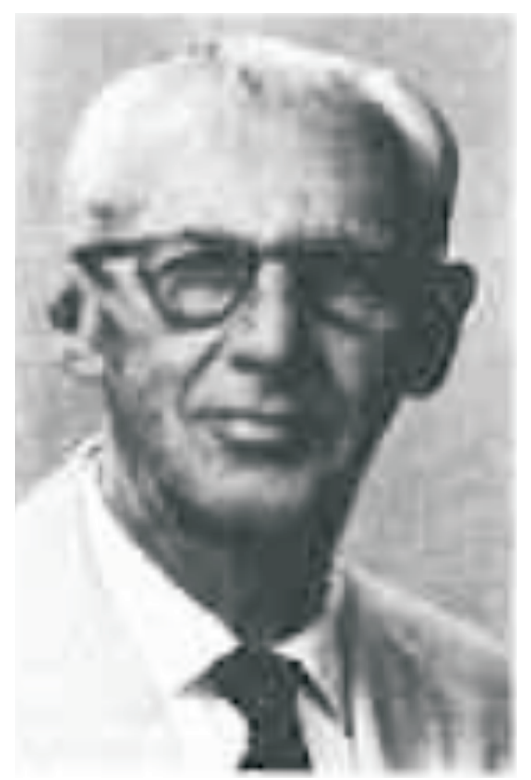

Figure 10 J. Tucker. ${ }^{49}$

17th Annual Convention, Rhodes University Campus in Port Elizabeth

The Eastern Province Section hosted the 17th Annual Convention of SACI from 15 to 19 July 1963 at the Rhodes University Bird Street campus. The organizing Chairman was J. Tucker. On the first day of lectures a Symposium was held which dealt with Municipal Chemistry, covering water supplies (H. Bruggeman), gas supplies (Dr E.G. White), industrial effluents, drain water and aspects of pollution (National Water Institute, Pretoria). There were further lectures covering synthetic detergents (D.W. Osborn), atmospheric pollution (Dr E.C. Halliday), the treatment of metal finishing waters (J.J. Barnard) and the chemistry of beer (W.A. Potgieter). ${ }^{50}$

The following day featured a Symposium on Physical Chemistry in the morning, whilst in the afternoon there was one on Analytical Chemistry. The Physical Chemistry Symposium had the following lectures: 'Large-scale gas chromatography' (Prof. V. Pretorius), 'IR absorption spectrum of mono-deuteromethane' (Prof. E.C. Leisegang, G.A. Mears), 'The thermal decomposition of ammonium vanadate' (C.S. Bergstrom), 'The limiting efficiency of analytical gas chromatography' (Prof. V. Pretorius) and 'The Torpedo friction test for explosives' (Dr G.S. Harrison)..$^{50}$

The Analytical Chemistry session featured lectures on hypophosphite as a reducing agent in wool (O.A. Swanepoel), colorimetric determination of phosphorus in fertilizers (J.D. Leonard), trace impurities in a sample of natural glycerine (Dr H. Keppler), determination of Cr using AA (Dr Butler) and vacuum spectroscopy as an analytical technique in the iron and steel industry (Dr Radmacher). ${ }^{50}$

The Organic Chemistry session was offered in Grahamstown at Rhodes University the following morning (July 18). It covered lectures on the synthesis and properties of cis- and trans-formylcrotonic acid (B. Burger), absolute configurations of some flavanones and flavan analogues (Dr D. Roux, S.E. Drewes), some aspects of resorcinol-formaldehyde condensation (Dr E. Little, W.E. Campbell) and the synthesis of polyene epoxides (Dr D. Schneider, Dr C.F. Garbers). ${ }^{50}$

The afternoon was dedicated to visits to the Leather Industries Research Institute and the Wool Textile Research Institute in Grahamstown. Finally, on the last day there was a Symposium entitled 'Methods of stimulating the growth of the Institute's membership'. 50

On 26 March 1965 Mr Tucker, Chairman of the E.P. Section, had the honour of presenting Dr O.A. Swanepoel from the SA Wool Textile Research Institute with the AECI Gold Medal in recognition of his two research papers which appeared in the Journal of the SA Chemical Institute. One of these papers was entitled: 'Reduction of cysteine and peptide-bound disulphides by hypophosphite and UV light ${ }^{51}$ and the other dealt with bonding strengths in proteins. ${ }^{52}$ The ceremony took place at Rhodes University. ${ }^{53}$

\section{Interaction of SACI with the Chemical Industry in the Region}

It is apparent from this article that there was significant contact between the EP Section of SACI and the local chemical industries. There were three important factors which contributed to the development of such industries in the region. Firstly, Port Elizabeth is an important harbour which facilitates the import and export of various chemicals and products. Secondly, the PE Technical College provided technical and academic support to industries, for example the tanning and pharmaceutical industries. And thirdly, Rhodes University in Grahamstown (Makhanda) had an excellent Chemistry Department headed by Prof. Barker, who had a keen insight and interest in applied chemistry. In those days the local chemical industries made use of the expertise available at these two academic institutions and 
certainly the EP Section of SACI facilitated that contact, as can be seen from the many lectures and factory visits organized by the Section and the important part played by industry in the National Conventions which took place in Port Elizabeth.

Certain of these chemical industries were intimately involved with the EP Section through contact with committee members or by providing the Chairman of the Section, as shown by Vincent Morris from Firestone and John Tucker from Algoa Sweets.

The scope of industrial participation covered a very wide range: the tanning industry, rubber companies, the cement industry, salt-pan works, wool and textile activities (dyeing), canning and sugar confectionaries, adhesive companies, car manufacturers, pharmaceutical industries and others.

The leather and tanning industry was very active in those days in PE and surroundings, with numerous tanneries, the biggest one being Bagshaw, Gibaud and $\mathrm{Co}$, which produced its one millionth pair of army boots in $1944 .{ }^{10}$ When the 1820 settlers arrived in PE, amongst them were 27 shoemakers, 5 tanners, 4 saddlers and other leather specialist. ${ }^{10}$ These people and their descendants went on to create the numerous tanneries in the area. As seen from this article A. Gardner played a leading role in both the E.P. Section of SACI and the leather / tanning industry, leading to the formation of LIRI centred at Rhodes under the guidance of Prof. Barker.

The two large tyre-producing companies in the area, Goodyear in Uitenhage and Firestone in Port Elizabeth, have been active for many years. From this article it is evident that very close ties were maintained between these industries and the Section, shown by the many lectures, factory visits and collaboration during the Conventions.

A staff-member, S.A. Spencer, of the cement industry was one of the first to join the committee in 1935 and gave a talk on the manufacture of cement. The food industries such as the canning, chocolate and sugar confectionaries were represented at committee level by two Chairmen: Dr P.K. van Gent and J. Tucker. The wool and textile industry featured prominently in the 1951 Convention with various sessions dedicated to synthetic fibres and the chemical treatment of wool.

The salt works out at Coega were started by an Italian chemical engineer by the name of Dr A. Rossi and visits were made to the plant and lectures given at Conventions. The adhesive industry was represented by Addis-Smith, whilst Aberdare Cables, the plastic industry, General Motors and the pharmaceutical industry were all involved with the Section at one time or another.

Finally, chemical engineers were accepted into the Section and several lectures were dedicated to various engineering aspects of the chemical industries. Two important people with an engineering background from PE were the brothers Ralph and Hymie Schauder, who played key roles in chemical activities in the region.

\section{Conclusion}

This article demonstrates that the Eastern Province Section of the South African Chemical Institute has been very active since its inception in 1935. Prof. William Barker from Rhodes University was the founding Chairman and he made a great impact on chemistry in the region for 12 years. There was very strong interaction between the Section and the chemical and applied industries, leading to the formation of a number of Research Organisations like the Leather Industries Research Institute and the South African Wool and Textile Research Institute. Meetings in the early stages of the Section were dominated by industrial and applied chemical topics such as leather, wool, rubber, plastics and food aspects like canning and sugar confectionary activities.
Chemical engineering topics were also considered such as gas production, wastes, corrosion problems in chemical plants and others. The applied chemical nature of SACI activities in these early years is well-illustrated by the programme of the first day of the 17th Annual Convention held in Port Elizabeth in 1963, which was entirely dedicated to Municipal Chemistry with such topics as water and gas supplies, industrial effluents, water and atmospheric pollution and the treatment of metal finishing waters. Maximum membership of the Section during the period 1935-1965 was 59 in 1953.

The respective Chairmen of this Section during these times were: Prof. William Barker (1935-1947), Laurence Frederick Addis-Smith (1947-1949), Dr E.P. Stevens (1949-1952), Dr C.A. Maunder-Foster (1952-1953), R. Schauder (1953-1957), Dr P.K. van Gent (1957-1961), and J Tucker (1961-1965).

It should be noted that all these men were very interested in applied chemistry and as such fostered good relations with the chemical and allied industries.

\section{${ }^{8}$ ORCID ID}

P. Loyson: (iD orcid.org/0000-0002-5487-2037

\section{References}

1 F.W. Fox, Report of Council, S. Afr. Chem. Institute Proceedings, July 1934-June 1935, p. 17.

2 K. Mathieson, A history of SACI 1912-1962,50 golden years, The S. Afr. Industrial Chemist, 1963 Jan., p. 19.

3 P.G. Van Rooyen, Institute News, The S. Afr. Industrial Chemist, 1948 May, p. 97.

4 F.W. Fox, S. Afr. Chem. Institute Proceedings, July 1934-June 1935, p. 3.

5 Photograph taken by the author.

6 en.wikipedia.org Rhodes University, Herbert Baker Tower (last visited 11 December 2019)

7 W.F. Barker, Report for the year, S. Afr. Chem. Institute Proceedings, July 1935-June 1936, p. 18.

8 W.F. Barker, Report for the year, S. Afr. Chem. Institute Proceedings, July 1940-June 1941, pp. 25-26.

9 F.W. Fox, S. Afr. Chem. Institute Proceedings, July 1936-June 1937, p. 18.

10 S. Shuttleworth, From Riempies to Fashion Shoes, J. Eggers, Port Elizabeth, South Africa, 1982.

11 S.G. Shuttleworth, Memoirs of an Industrial Boffin, E.H.Walton, Port Elizabeth, South Africa, 1985

12 W.F. Barker, List of lectures-E.P. Section, S. Afr. Chem. Institute Proceedings, July 1935-June 1936, p. 21.

13 W.F. Barker, Annual Report E.P. Section for 1936-1937, S. Afr. Chem. Institute Proceedings, July 1936-June 1937, p. 27.

14 W.F. Barker, Annual Report E.P. Section for 1937-1938, S. Afr. Chem. Institute Proceedings, July 1937-June 1938, p. 26.

15 W.F. Barker, Annual Report E.P. Section for 1938-1939, S. Afr. Chem. Institute Proceedings, July 1938-June 1939, p. 25.

16 W.F. Barker, Annual Report E.P. Section for 1939-1940, S. Afr. Chem. Institute Proceedings, July 1939-June 1940, p. 27.

17 W.F. Barker, Annual Report E.P. Section for 1940-1941, S. Afr. Chem. Institute Proceedings, July 1940-June 1941, p. 28.

$18 \mathrm{http}: / /$ www.saci.co.za/past presidents.html (accessed 11 Dcember 2019

19 Obituary William Frances Barker, CHEMSA, December 1974, p. 39.

20 M.E. Brown, D.J. Eve, P.T. Kaye, D.E.A. Rivett and G.M. Watkins, S. Afr. J. Sci., 100, 2004, pp. 530-538. 00382353.

21 Stanley Shuttleworth, From Riempies to Fashion Shoes, J. Eggers, Port Elizabeth, South Africa, 1982, pp. 23-31.

22 P. Loyson, Early Pharmacy Teaching in Port Elizabeth, NMU, Port Elizabeth, 2016, pp. 2-29.

23 P. Loyson, The First Chemistry Department in Port Elizabeth, Sun Press, 2017, pp. 8-10.

24 R. Schauder, 18th Annual EP Section Report 1953-1954, The S. Afr. Industrial Chemist, November 1954, p. 19.

25 W.F. Barker, Annual Report EP Section for 1946-1947, S. Afr. Chem. Institute Proceedings, July/August 1947, p. iv. 
26 L.F. Addis-Smith, Annual Report E.P. Section 1947-48, The S. Afr. Industrial Chemist, October 1948, p.x.

27 P.G. van Rooyen, Eastern Province Section News, The S. Afr. Industrial Chemist, August 1948, p. 159.

28 E.P. Stevens, 14th Annual E.P. Report 1949-1950, The S. Afr. Industrial Chemist, November 1950, p. 215.

29 T.K. Cordes, Mr Lindemann visits E.P. Section, The S. Afr. Industrial Chemist, December 1949, p. 237.

30 E.P. Stevens, 15th Annual Report E.P. Section for 1950-1951, The S. Afr. Industrial Chemist, October 1951, p. 199.

31 G.E.M. Milner, Fifth Chemical Convention, The S.Afr. Industrial Chemist, August 1951, pp. 142-145.

32 R. Schauder, 17th Annual Report E.P. Section, The S. Afr. Industrial Chemist, October 1953, p. 183.

33 R. Schauder, 18th Annual Report E.P. Section, The S. Afr. Industrial Chemist, November 1954, p. 236.

34 R. Schauder, 19th Annual Report E.P. Section, The S. Afr. Industrial Chemist, November 1955, p. 203.

35 H. Schauder, Waste - South Africa's challenge and opportunity, The S. Afr. Industrial Chemist, June 1956, pp. 132-135.

36 Private communication from Hyman Schauder's son Donald in Australia (15 March 2019)

37 Simon Keeble, Life Members of SACI, ChemSA, August 1987, p. 202.

38 P.K. van Gent, Annual Report E.P. Section for 1957-58, The S. Afr. Industrial Chemist, June 1958, p.167.

39 K.A. Murray, Institute News, The S. Afr. Industrial Chemist, July 1957, p. 123.

40 K.A. Murray, 12th Convention Programme, The S. Afr. Industrial Chemist, May 1958, p. 83.
41 P.K. van Gent, 12th Annual Convention in Port Elizabeth, The S. Afr. Industrial Chemist, November 1958, pp. 208-210.

42 P.K. van Gent, 23rd Annual Report E.P. Section, The S. Afr. Industrial Chemist, June 1959, p. 137.

43 P.K. van Gent, SACI News E.P. Section, The S. Afr. Industrial Chemist, September 1958, p.167.

44 P.K. van Gent, 24th Annual Report E.P. Section, The S. Afr. Industrial Chemist, July 1960, pp. 138-139.

45 K.A. Murray, Society News E.P. Section, The S. Afr. Industrial Chemist, March 1960, p. 58.

46 K.A. Murray, Society News E.P. Section, The S. Afr. Industrial Chemist, August 1961, p. 148.

47 P.K. van Gent, The work of the government food chemist, The S. Afr. Industrial Chemist, January 1959, pp. 2-5.

48 P.K. van Gent, The accuracy of the South African modified KozelkaHine method for the blood-alcohol determination, The S. Afr. Industrial Chemist, June 1965, pp. 102-105.

49 George Warman, Institute News, Obituary, S. Afr. Chem. Processing: December - January 1966/67, p.152.

50 K. Mathieson, 17th Annual Convention in Port Elizabeth, The S. Afr. Industrial Chemist, May 1963, pp. 122-126.

51 O.A. Swanepoel, Reduction of cysteine and peptide-bound disulphides by hypophosphite and UV light, J. S. Afr. Chem. Inst., Oct 1963, 16, no. 2, pp. 31-37.

52 O.A. Swanepoel, Die gebruik van die lengtemodules bij die ondersoek van die kruisbindingdigtheid van protein, J. S. African Chem. Inst., Oct 1963, 16, no. 2, pp. 55-58.

53 K. Mathieson, Eastern Province Section, The S. Afr. Industrial Chemist, April 1965, p. 71. 